\title{
Selective Ortho Hydroxylation of Nitrobenzene with Molecular Oxygen Catalyzed by the $\mathrm{H}_{5} \mathrm{PV}_{2} \mathrm{Mo}_{10} \mathrm{O}_{40}$ Polyoxometalate
}

\author{
Alexander M. Khenkin, ${ }^{a}$ Lev Weiner ${ }^{\mathrm{b}}$ and Ronny Neumann ${ }^{\mathrm{a} *}$ \\ (a) Department of Organic Chemistry and (b) Chemical Research Support Unit, Weizmann \\ Institute of Science, Rehovot, Israel, 76100
}

\section{Supplementary Information}

\section{Experimental Section}

Materials. The $\mathrm{H}_{5} \mathrm{PV}_{2} \mathrm{Mo}_{10} \mathrm{O}_{40} \bullet 34 \mathrm{H}_{2} \mathrm{O}$ polyoxometalate was prepared according to the literature (Tsigdinos, G. A.; Hallada, C. J. Inorg. Chem. 1968, 7. 437-441). Nitrobenzene was ACS grade, $+99 \%$, and used from a pristine bottle without further purification (no impurities were detected by GC). ${ }^{18} \mathrm{O}_{2}$ (96.1\% ${ }^{18} \mathrm{O}$ enrichment) was purchased from Enritech (now D-Chem). $\mathrm{H}_{2}{ }^{18} \mathrm{O}$ $\left(94.3 \%{ }^{18} \mathrm{O}\right.$ enrichment) was purchased Rotem Chemicals. Nitrobenzene- $\mathrm{d}_{5},{ }^{15} \mathrm{~N}$-nitrobenzene, phenyl-t-butylnitrone and $1,1^{\prime}$-azobis(cyclohexanecarbonitrile) were all commercial products and used without purification.

Instruments. GC - FID detector (HP 6890), He eluent, column 50\% phenylmethylsilicone (30 m, $32 \mathrm{~mm}, 0.25 \mu \mathrm{m}$ coating). GC - MS (HP 5973), He eluent, column 5\% phenylmethylsilicone (30 m, $25 \mathrm{~mm}, 0.25 \mu \mathrm{m}$ coating $).{ }^{1} \mathrm{H}$ NMR $(250 \mathrm{MHz})$ and ${ }^{31} \mathrm{P}$ NMR $(101.27 \mathrm{MHz})$ were carried out on a Bruker Avance 250 DPX instrument and ${ }^{15} \mathrm{~N}$ NMR $(50.69 \mathrm{MHz})$ were carried out on a Bruker Avance 500. X-band EPR measurements (Bruker ELYXIS 500) were carried were at room temperature in a flat cell and collected by averaging 5 scans (frequency $-9.8193 \mathrm{GHz}$; microwave power $-0.04 \mathrm{~W}$; time constant $-.16 \mathrm{~s}$; field modulation $-100 \mathrm{KHz}$ ).

Typical reaction procedures. Reactions were carried out in $25 \mathrm{~mL}$ glass pressure tubes $(0.2-2$ bar $\mathrm{O}_{2}$ ) or a $25 \mathrm{~mL}$ Hastelloy Parr stirred autoclave $\left(>2\right.$ bar $\left.\mathrm{O}_{2}\right)$. Typically, $10 \mathrm{mM}$ solutions of $\mathrm{H}_{5} \mathrm{PV}_{2} \mathrm{Mo}_{10} \mathrm{O}_{40} \bullet 34 \mathrm{H}_{2} \mathrm{O}$ in $1 \mathrm{~mL}$ nitrobenzene were charged with $\mathrm{O}_{2}$ after flushing the solution three times and placed in a thermostated oil bath at $140{ }^{\circ} \mathrm{C}$. The progress of the reaction was monitored by GC using as reference standards of all three regioisomers of nitrophenol. The product identity and reaction selectivity was double checked both by GC-MS and ${ }^{1} \mathrm{H}$ NMR. 
Figure S1. The rate of nitrobenzene oxidation as a function of catalyst concentration.

Reaction rates were measured from reactions at 5-20 mM $\mathrm{H}_{5} \mathrm{PV}_{2} \mathrm{Mo}_{10} \mathrm{O}_{40} \cdot 34 \mathrm{H}_{2} \mathrm{O}$ in nitrobenzene at $140{ }^{\circ} \mathrm{C}$ under 2 bar $\mathrm{O}_{2}$. A generalized rate equation is rate $=\mathrm{d}[$ nitrophenol] $/ \mathrm{dt}$ $=\mathrm{k}\left[\mathrm{PhNO}_{2}\right]^{\mathrm{a}}\left[\mathrm{H}_{5} \mathrm{PV}_{2} \mathrm{Mo}_{10} \mathrm{O}_{40}\right]^{\mathrm{b}} \mathrm{P}_{\mathrm{O} 2}{ }^{\mathrm{c}}$. Since nitrobenzene is in large excess the rate can be well approximated as rate $\approx \mathrm{k}_{\mathrm{obs}}\left[\mathrm{H}_{5} \mathrm{PV}_{2} \mathrm{Mo}_{10} \mathrm{O}_{40}\right]^{\mathrm{b}} \mathrm{P}_{\mathrm{O} 2}{ }^{\mathrm{c}}$. A set of reactions at different $\mathrm{H}_{5} \mathrm{PV}_{2} \mathrm{Mo}_{10} \mathrm{O}_{40}$ concentrations and a plot of $\log ($ rate $)$ versus $\log \left[\mathrm{H}_{5} \mathrm{PV}_{2} \mathrm{Mo}_{10} \mathrm{O}_{40}\right]$ will give as the slope the reaction order in $\mathrm{H}_{5} \mathrm{PV}_{2} \mathrm{Mo}_{10} \mathrm{O}_{40}$ catalyst. slope $=1.03 ; \mathrm{r}^{2}=0.993$. The reaction is first order in $\mathrm{H}_{5} \mathrm{PV}_{2} \mathrm{Mo}_{10} \mathrm{O}_{40}$.

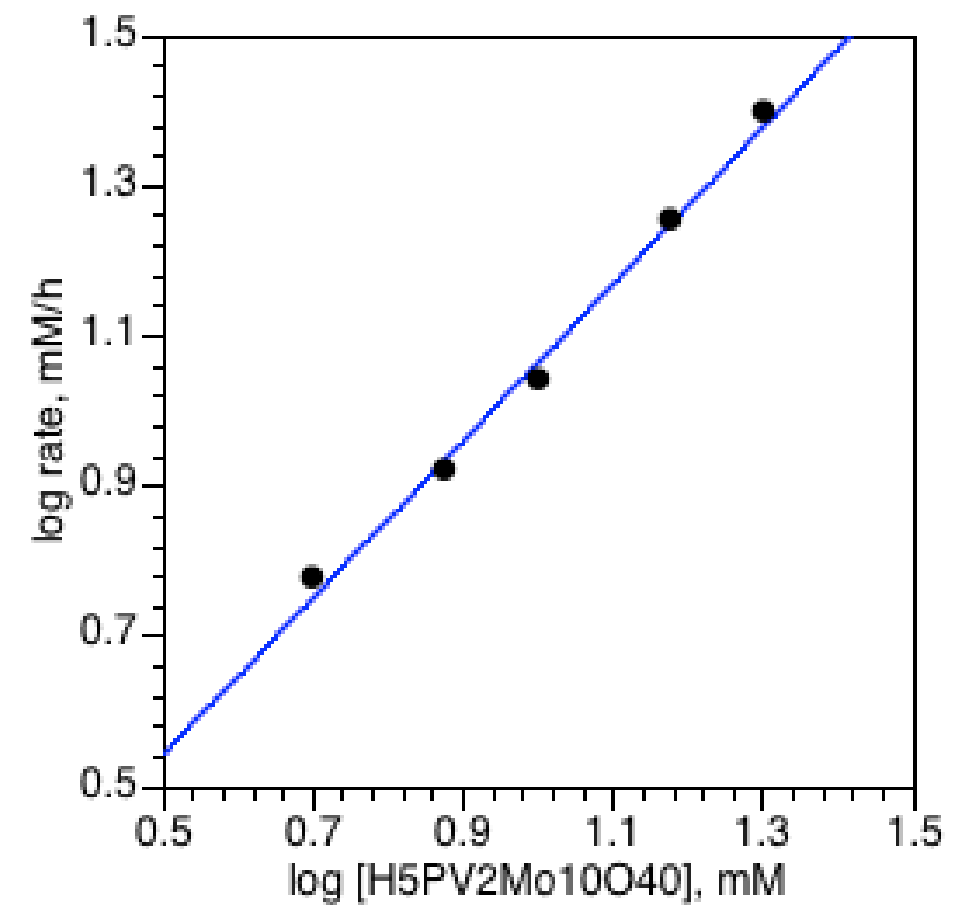


Figure S2. The rate of nitrobenzene oxidation as a function of oxygen pressure.

Reaction rates were measured from reactions at $10 \mathrm{mM} \mathrm{H}_{5} \mathrm{PV}_{2} \mathrm{Mo}_{10} \mathrm{O}_{40} \cdot 34 \mathrm{H}_{2} \mathrm{O}$ in nitrobenzene at $140{ }^{\circ} \mathrm{C}$ under $0.2-8$ bar $\mathrm{O}_{2}$. A generalized rate equation is rate $=$ $\mathrm{d}[$ nitrophenol $] / \mathrm{dt}=\mathrm{k}\left[\mathrm{PhNO}_{2}\right]^{a}\left[\mathrm{H}_{5} \mathrm{PV}_{2} \mathrm{Mo}_{10} \mathrm{O}_{40}\right]^{\mathrm{b}} \mathrm{P}_{\mathrm{O} 2}{ }^{c}$. Since nitrobenzene is in large excess the rate can be well approximated as rate $\approx \mathrm{k}_{\text {obs }}\left[\mathrm{H}_{5} \mathrm{PV}_{2} \mathrm{Mo}_{10} \mathrm{O}_{40}\right]^{\mathrm{b}} \mathrm{P}_{\mathrm{O} 2}{ }^{\mathrm{c}}$. A set of reactions at different oxygen pressures and a plot of $\log ($ rate $)$ versus $\log \left(\mathrm{P}_{\mathrm{O} 2}\right)$ will give as the slope the reaction order in oxygen. slope $=1.06 ; \mathrm{r}^{2}=0.989$. The reaction is first order in dioxygen.

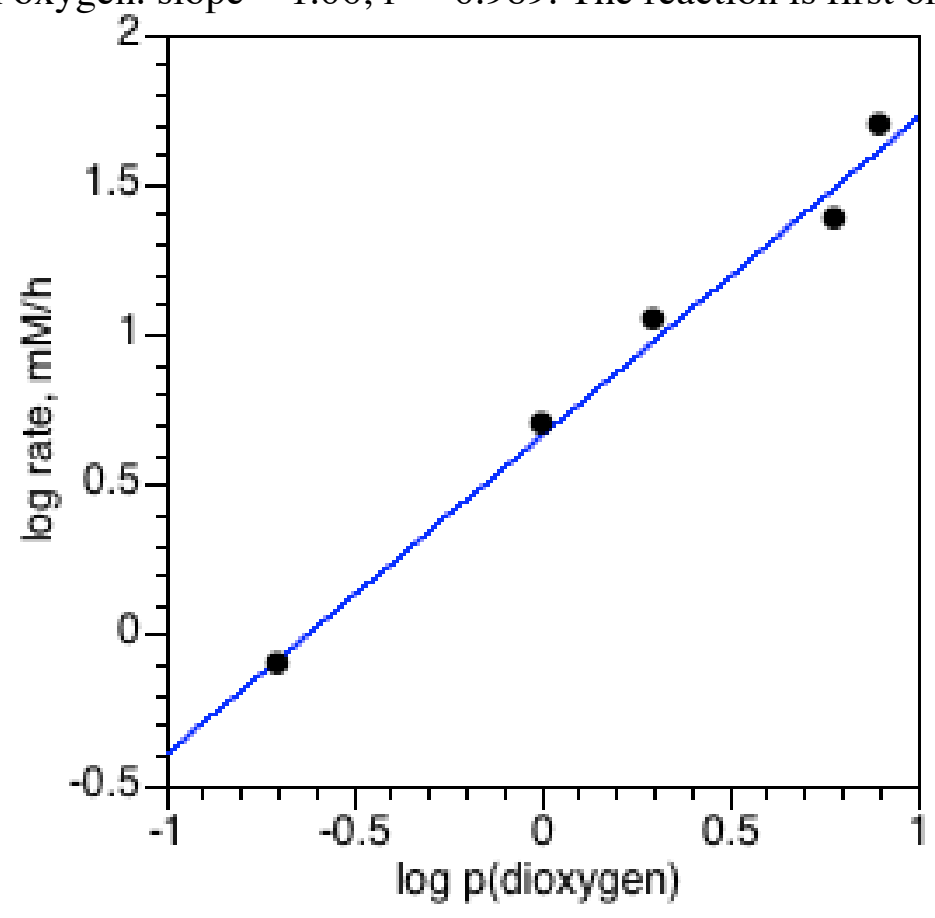


Figure 3S. The amount of 2-nitrophenol formed after $16 \mathrm{~h}$ as a function of the amount water in the reaction medium.

Reaction were carried out with $10 \mathrm{mM} \mathrm{H} \mathrm{PV}_{2} \mathrm{Mo}_{10} \mathrm{O}_{40} \bullet 34 \mathrm{H}_{2} \mathrm{O}$ in nitrobenzene at $140{ }^{\circ} \mathrm{C}$ under 2 bar $\mathrm{O}_{2}$. Conversion was measured after $16 \mathrm{~h}$. The value for $0 \mu \mathrm{mol} \mathrm{H}_{2} \mathrm{O}$ was obtained by adding molecular sieve $4 \AA$ to the mixture; under these conditions there was no reaction. The other points were obtained by adding 0,500 and $1000 \mu \mathrm{mol} \mathrm{H}_{2} \mathrm{O}$, respectively.

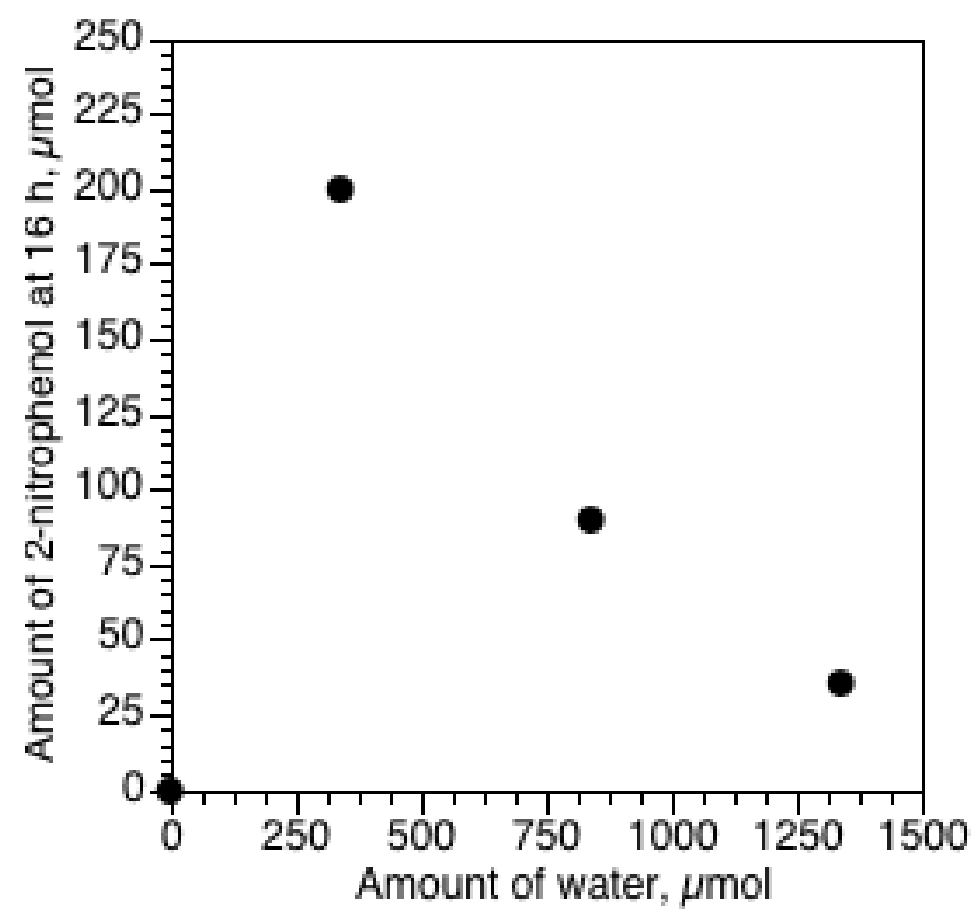

